Louisiana State University

LSU Digital Commons

Faculty Publications

Department of Oceanography \& Coastal

Sciences

1987

\title{
Spoil Banks: Effects on a Coastal Marsh Water-Level Regime
}

Erick M. Swenson

R. Eugene Turner

euturne@lsu.edu

Follow this and additional works at: https://digitalcommons.Isu.edu/oceanography_coastal_pubs

Recommended Citation

Swenson, E. M., \& Turner, R. (1987). Spoil Banks: Effects on a Coastal Marsh Water-Level Regime., 24,

599-609. Retrieved from https://digitalcommons.Isu.edu/oceanography_coastal_pubs/163

This Article is brought to you for free and open access by the Department of Oceanography \& Coastal Sciences at LSU Digital Commons. It has been accepted for inclusion in Faculty Publications by an authorized administrator of LSU Digital Commons. For more information, please contact ir@lsu.edu. 


\title{
Spoil Banks: Effects on a Coastal Marsh Water-Level Regime
}

\author{
Erick M. Swenson and R. E. Turner \\ Coastal Ecology Institute, Center for Wetland Resources, Louisiana State \\ University, Baton Rouge, LA 70803, U.S.A.
}

Received 25 October 1985 and in revised form 5 September 1986

Keywords: coasts; marshes; water-level mark; spoilage; hydrology; Louisiana

\begin{abstract}
Above- and below-ground water-level fluctuations were measured in the marshes south of New Orleans, Louisiana, between November 1982 and December 1983. The purpose of the program was to define the basic marsh water-level regime and to investigate how canal spoil banks may influence the water-level regime. Two study areas were used: (1) a control area, defined as a section of marsh with unrestricted hydrologic connection to an adjacent bayou; and, (2) a partially-impounded area, defined as an area with limited hydrologic connection to an adjacent bayou due to the presence of dredged canal spoil banks. Data sources included marsh water levels from gages deployed at three sites within the study areas and water levels from the adjacent bayous obtained from the tide gages of U.S. Army Corps of Engineers.

Data from all marsh gage sites showed a similar pattern with a distinct surface and subsurface diurnal tidal signal superimposed upon other, larger scale events. These larger scale events correspond to the passage of weather fronts. The data also indicated that a significant amount of water-level fluctuation in the marshes occurs below ground.

A comparison of the control area and the partially-impounded site indicated that the spoil banks changed the response of the marsh water levels to the forcing from the bayou, with the result that the partially-impounded area: (1) was flooded 141 hours more per month than the control area; (2) had fewer, but longer flooding events; (3) had fewer but longer drying events; and (4) reduced water exchange, both above and below ground.
\end{abstract}

\section{Introduction}

Wetland management and use often involve the direct or indirect manipulation of the hydrologic regime. Such manipulation may, or may not, be intentional and can result from many different activities. Canals and their resulting spoil banks, weirs, and tidal gates have been used in wetlands to assist navigation, regulate water levels and salinity, and implement management plans. Many of the canals and spoil banks in south Louisiana were constructed solely to assist oil and gas recovery operations. Spoil banks, in conjunction with weirs, plugs or water-control structures, have also been built to control water levels for over-wintering ducks. However, spoil banks have also been implicated as one of the contributing factors to the high wetland loss rate in southern Louisiana. 
The annual loss rate is currently estimated to be about $0.8 \%$ of the existing marsh (Scaife et al., 1983). Several studies (e.g., Adams et al., 1978; Craig et al., 1979; Turner et al., 1982; Scaife et al., 1983) have noted the empirical relationship between erosion and canal-and spoil-bank density. The connection between spoil banks and wetland loss is presumably through their influence on marsh hydrologic conditions, which in turn influence biotic and physical factors important in sustaining land-building processes in an otherwise sinking (through sediment compaction and sea-level rise) deltaic coast. Despite the clear ecological, economic, and social value of this enormous wetland area (about $41 \%$ of the U.S. coastal wetlands; Turner \& Gosselink, 1975) there has been little detailed field research on the hydrology of these marshes or on the effects of spoil banks on wetland hydrology. Many authors (Craig et al., 1979; Gael \& Hopkinson, 1979; Turner et al., 1982, 1984) have implicated hydrologic changes as the major mechanism for canal and spoilbank influence on wetland (marsh) ecology. However, none of these studies have any detailed field measurements of the hydrologic regime. It was the purpose of this study to determine the effects of spoil banks on a marsh hydrologic regime and how this might influence future management of the southern Louisiana marsh ecosystem.

\section{Materials and methods}

\section{Study sites}

The study areas are located in a brackish marsh south of New Orleans, Louisiana (Figure 1), in the still active Golden Meadow oil and gas field. We used two areas: (1) a control area, which had a natural berm along a major bayou; and (2) a partially-impounded area where about $75 \%$ of the natural berm had been replaced by a dredged canal spoil bank, which limited the hydrologic connection to the adjacent bayou. Water level gages were deployed at two sites within the partially-impounded area and one site within the control areas.

The control area (Figure 1), was approximately 33.4 ha and was vegetated with a mixture of Spartina alterniflora and Spartina patens, the most commonly occurring emergent marsh vegetation in this general area (Chabreck, 1972). The bayou had a natural levee 1-2 $\mathrm{m}$ wide, with an average berm height about $0.1 \mathrm{~m}$ higher than the adjacent marsh. In an earlier study, De-Laune et al. (1983), noted berm heights of about $0 \cdot 1 \mathrm{~m}$ for a natural Spartina alterniflora marsh in Barataria Bay, Louisiana. It was because of the natural edge along the bayou that this area was chosen for a control where there was a noticeable 'edge effect' with much more robust marsh vegetation along the bayou bank. The water-level gage was installed on the marsh surface at a site about $50 \mathrm{~m}$ inland from the edge of the Grand Bayou.

The partially-impounded area (Figure 1) was vegetated by a mixture of Spartina alterniflora and Spartina patens and covered about $7 \cdot 5$ ha. At this site, the natural edge along Grand Bayou had been replaced by a spoil bank, and the northern and southern edges of the area were also formed by canal spoil banks. It was estimated that the spoil banks cover about $75 \%$ of the perimeter; hence, the site is referred to as partiallyimpounded. Water-level gages were placed at two sites within the area: (1) Impound-1 was on a firm section of marsh about $50 \mathrm{~m}$ inland from Grand Bayou; (2) Impound-2 was installed on the edge of a large pond located about $50 \mathrm{~m}$ inland from the edge of the canal which forms the southern boundary. A linear correlation of Impound-1 to Impound-2 indicated no significant difference between the water-level fluctuations at the two sites. 


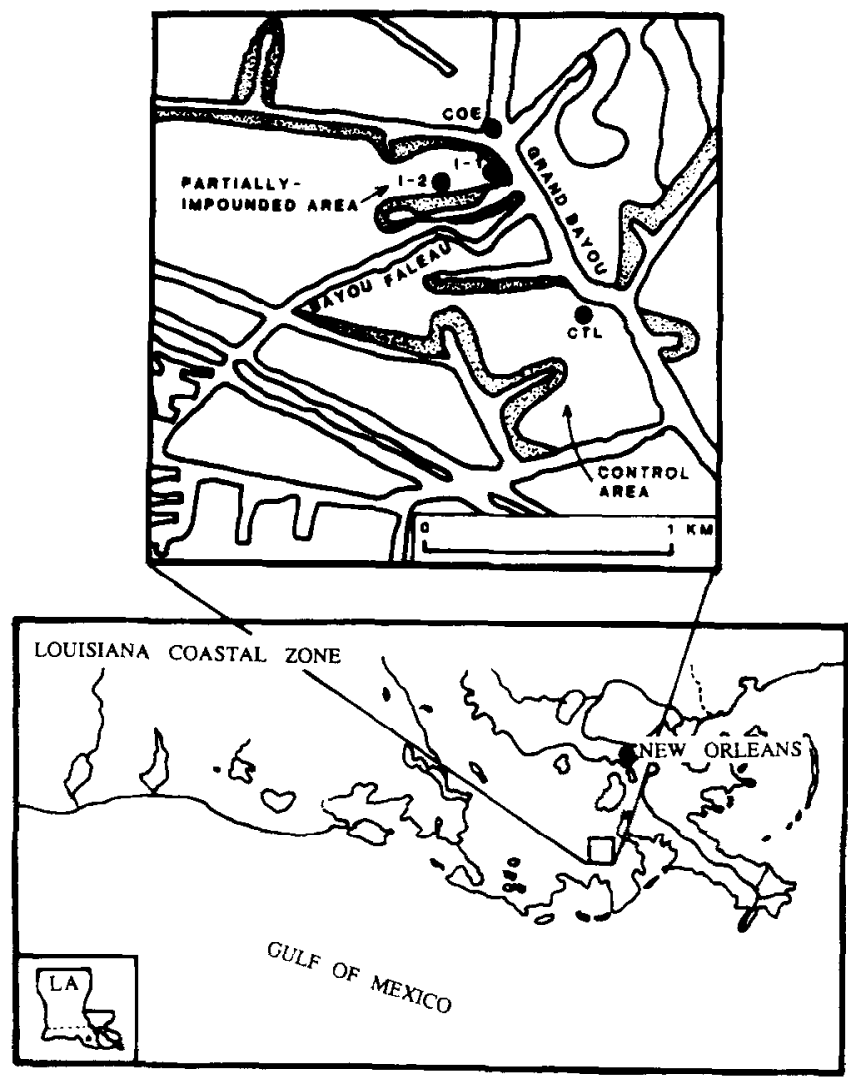

Figure 1. Generalized map of Louisiana coastal zone showing the study location south of New Orleans. The insert presents a detailed map of the study location, showing the water-level gage sites (I-1, Impound-1; I-2, Impound-2; COE, Corps. of Engineers; CTI, control) and the canal geometry. The stippled areas are spoil banks.

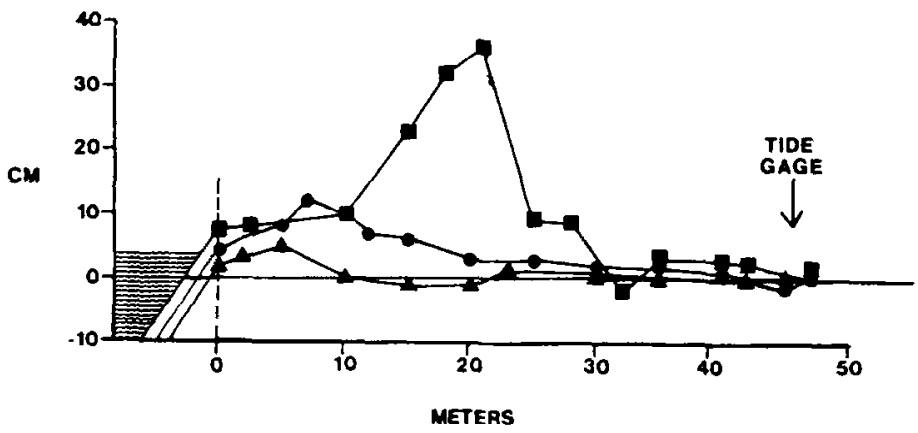

Figure 2. Marsh elevation transects from each of the gage sites. The height of the marsh (above the water surface at the time of the survey) is indicated as a function of distance into the marsh from the waters' edge. $\Delta$, CTL;,$I-1 ; \boldsymbol{D}, \mathrm{I}-2$.

Thus, the data presented in this paper are from the Impound-1 gage site, which had the longest record.

The relative heights of the marsh and the water-level gages were surveyed using a self-leveling Leitz level and stadia rod. Figure 2 presents the results of the survey. Along 


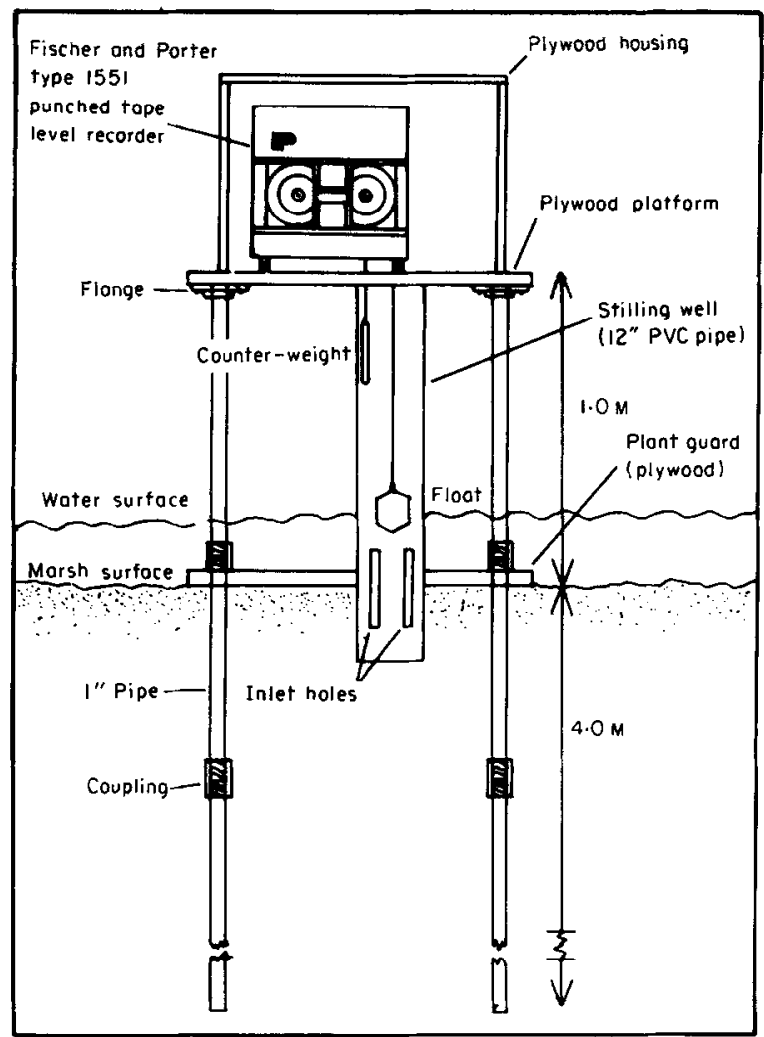

Figure 3. Schematic diagram illustrating the water level gage installation.

the Grand Bayou edge, the spoil bank at the Impound-1 gage site was about $0 \cdot 10-0 \cdot 15 \mathrm{~m}$ higher than the natural levee along Grand Bayou at the control area (CTL gage site). The spoil bank along the canal at the Impound-2 gage site was about $20 \mathrm{~m}$ wide and 0.40 high.

\section{Data collection}

Water levels were measured with level gages and recorded at hourly intervals on paper tape (Fisher and Porter type 1551). Installation (Figure 3) consisted of a plywood platform located about $1.0 \mathrm{~m}$ above the marsh surface. A $30-\mathrm{cm}$ diameter stilling well suspended from the platform housed the measuring float. The stilling well was dug into the marsh, resulting in an operating range from approximately $0.6 \mathrm{~m}$ below marsh surface to $1.0 \mathrm{~m}$ above marsh surface. The gages were serviced every other month, at which time data tapes were collected, the batteries changed and the clock checked. The worst drift for the clock was $1.0 \mathrm{~h}$ month ${ }^{-1}$. The marsh surface was quite 'bumpy', with elevation differences between the vegetation clumps and mud surface of about $0.04 \mathrm{~m}$. Therefore, for this study, the marsh surface was defined to be the top of the plywood plant guard which formed the base of the water-level measuring station. The gages were adjusted to record water levels relative to the marsh surface, as defined above. During servicing, this base level setting of the gages was also checked.

Water levels in Grand Bayou, near the study areas, were measured at a nearby gage (Figure 1) maintained by the U.S. Army Corps of Engineers (COE). Copies of the data records from this gage were supplied to us by the Corps. 


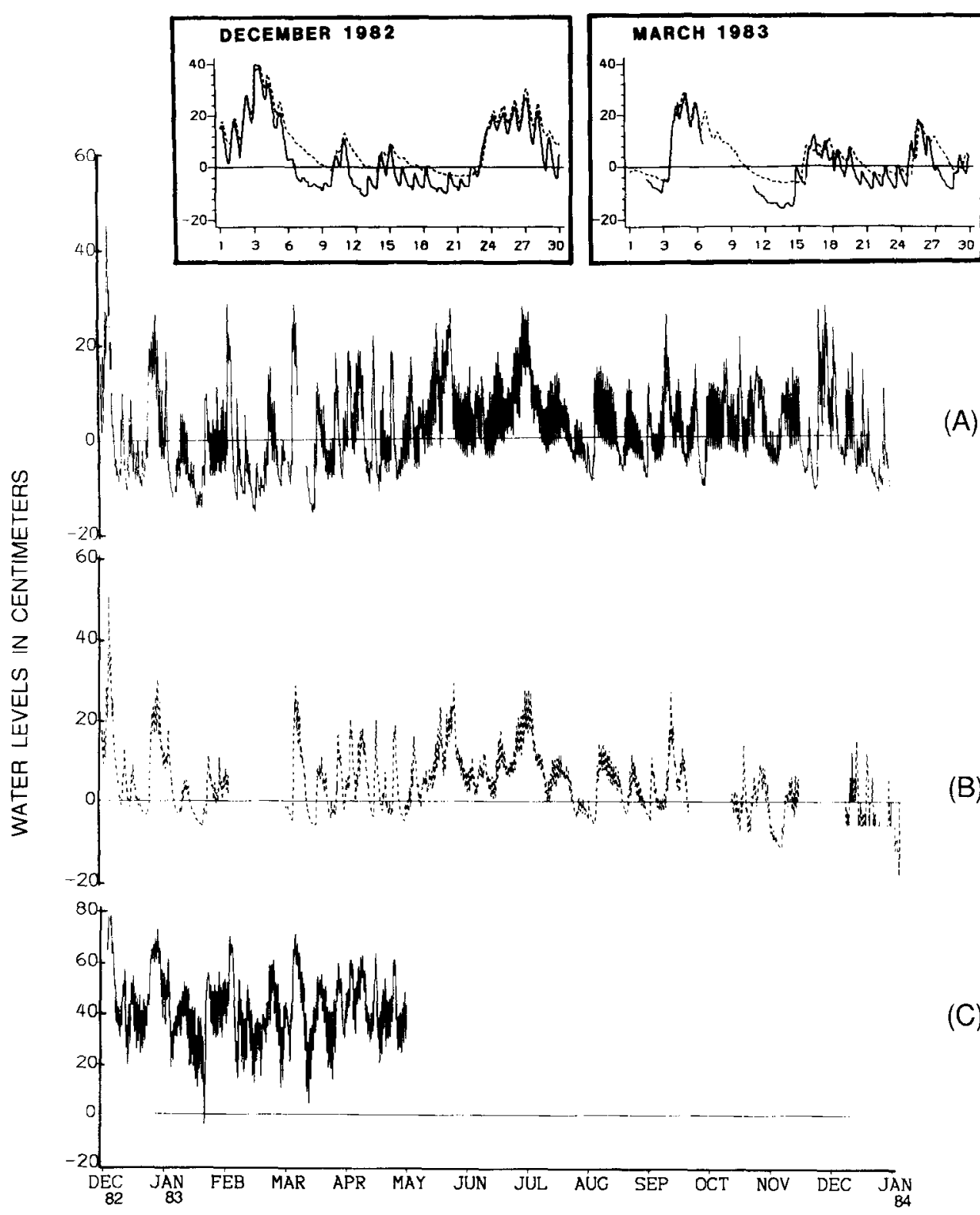

Figure 4. Raw (unfiltered) water level time series data from: (A) the control area, (B) the partially-impounded area, and (C) Grand Bayou for December 1982 thru April 1983. The bayou water levels are in centimeters relative to National Geodetic Vertical Datum (NGVD). The marsh water levels are in centimeters above or below the marsh surface. Boxes at top present detailed time series of plots of water levels from the control area (solid line) and the partially-impounded area (dashed line), for December 1982 and March 1983.

\section{Data analyses}

The data were analysed using Louisiana State University's IBM 3083 computer with the Statistical Analysis Systems software (SAS Institute Inc. 1981, 1982a,b). Because all of the data were collected in a time series format, the same analysis procedures were used for 
each data set. The Bayou data (chart-recorder records) were digitized by hand at threehour intervals. The marsh water levels (punched paper type) were read by machine at one-hour intervals. The digitized data were then transferred to the LSU mainframe computer, checked for errors, and converted to metric units. Any correction factors needed to adjust for gage base-level drift were applied at this time. The data were averaged by month to obtain summary statistics of: (1) mean below-ground water levels; (2) mean above-ground water levels; (3) percentage of the total fluctuations occurring belowground; and (4) the percentage of time the marsh is flooded.

Water exchange into and out of the marsh was estimated from the water-level data using the procedures described below. The first derivative of the water level versus time curves was calculated; the first derivative is the change in water level over a one-hour interval (the sampling interval). This change with time was expressed as a water volume exchange per unit area $\left(\mathrm{m}^{2}\right)$ of marsh. For example, a water-level drop of $10 \mathrm{~cm}$ corresponds to a volume exchange of $0 \cdot 10 \mathrm{~m}^{3} \mathrm{~h}^{-1}$ per $\mathrm{m}^{2}$ of marsh. The time history of volume flux was then numerically integrated to obtain total flux values for above- and below-ground water levels for both flood and ebb tides. The integration followed the general form of:

$$
R_{\mathrm{p}}=\sum_{i=0}^{n} f\left(W_{i}\right) \Delta X
$$

where: $R_{\mathrm{p}}=$ estimated area under the curve; $f\left(W_{i}\right)=$ height of curve relative to marsh surface at time $i, \Delta X=$ sampling interval $(1 \mathrm{~h}) ; n=$ total time intervals. For this analysis, three types of sums were calculated: (1) $f\left(W_{i}\right)_{\min }=$ minimum curve height during sample period; (2) $f\left(W_{i}\right)_{\max }=$ maximum curve height during sample period; (3) $f\left(W_{i}\right)_{\mathrm{avg}}=$ (minimum + maximum)/2.

The analysis, therefore, yielded estimates for the average area under the curve ( 3 ), along with an estimate of the minimum (1) and maximum (2) range. In making these calculations, it was assumed that any change in water level (either above- or below-ground) represented a layer or 'slab ' of water being exchanged, implying that the water surface on the marsh was level.

\section{Results}

Figure 4 presents time series water-level data for Grand Bayou, the control area, and the partially-impounded area between December 1982 and January 1984.

The most notable feature in Figure 4 is the dominant diurnal tidal signal, which is superimposed upon other larger scale water-level fluctuations. This diurnal signal is present in both the above-ground and below-ground portions of the water level signal. The amplitude of the below-ground tidal portion is around $5-10 \mathrm{~cm}$ while the aboveground tidal portion has amplitudes of $20-30 \mathrm{~cm}$. The larger scale fluctuations, with amplitudes of $40 \mathrm{~cm}$ or greater, result from wind-induced set-up caused by passing weather fronts (Swenson, 1983).

The difference in the way in which the control area and the partially-impounded area are coupled to the bayou is also evident. Although the water-level signals at both marsh sites mimic the signal in the bayou, the water-level signal in the partially-impounded area shows less short-term (tidal) fluctuation than the control area. The detailed inserts, which show data from December 1982 to March 1983, show that, although both reach the same levels during a flooding event, the partially-impounded area drains at a much slower rate. The control area also shows a great deal more water-level oscillation than the partially-impounded area. 

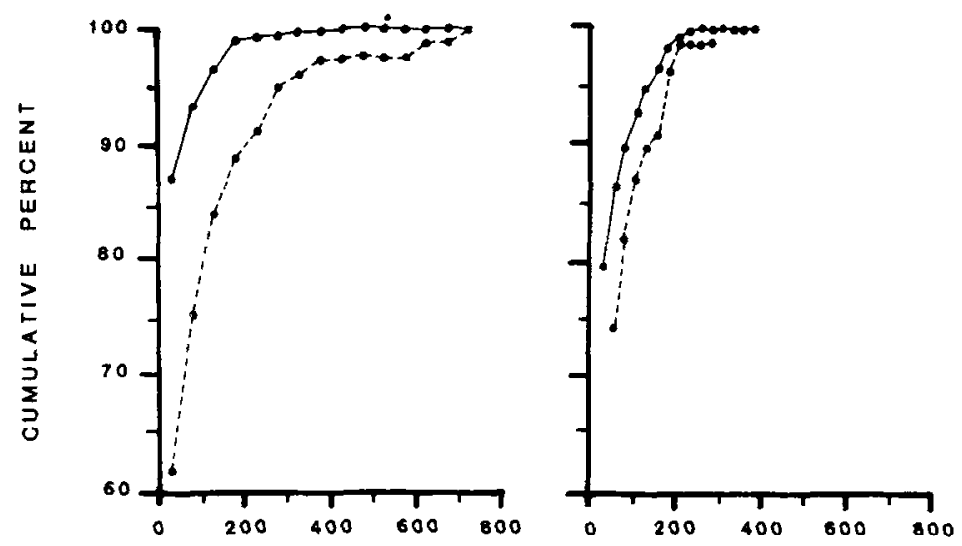

EVENT LENGTHS IN HOURS

Figure 5. Distribution of flooding event lengths (left) and dry time intervals (right) for the control area (solid line) and the partially-impounded marsh area (broken line). The horizontal axis is the length of the flooding event (in hours) and the vertical axis is the percentage of time that event occurred during the sampling period. The sample period covers the time from November 1982 to November 1984.

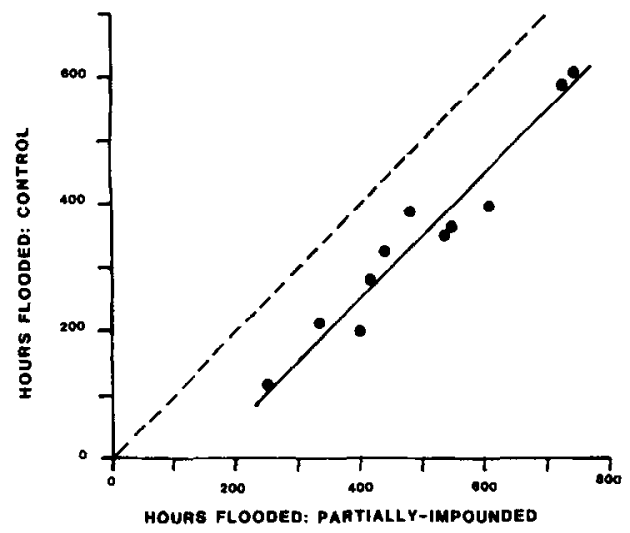

Figure 6. Plot of total hours flooded, for the month, at the control area (vertical axis) against total hours flooded, for the month, at the partially-impounded area. The broken line represents a one-to-one relationship; the solid line is the fitted line to the data points, given by $y=0.96 X-141 ; R^{2}=0.84$.

The length of each flooding event (number of hours the marsh was flooded) and the interval between each event was determined, on a monthly basis, from November 1982 to October 1984 (Figure 5). A comparison of flooding event lengths for each area indicates that flooding events shorter than $20 \mathrm{~h}$ occur $80 \%$ of the time in the control area, but only $28 \%$ of the time in the partially-impounded area. Similarly, flooding events which are longer than $100 \mathrm{~h}$ occur about $10 \%$ of the time in the control area, and about $37 \%$ of the time in the partially-impounded area. The mean flooding event lengths were $29.7 \mathrm{~h}$ and $149.9 \mathrm{~h}$ for the control and partially-impounded areas, respectively. Figure 6 is a plot of 
TABLE 1. Comparative summary statistics for the control and partially impounded marsh areas. August 1982-December 1983

\begin{tabular}{|c|c|c|}
\hline & Control & $\begin{array}{l}\text { Partially-impounded } \\
\text { site }\end{array}$ \\
\hline $\begin{array}{l}\text { Flooding } \\
\text { Number of events } \\
\text { Event length }(\mathrm{h})\end{array}$ & $\begin{array}{l}12 \cdot 92 \pm 02 \cdot 65 \\
29 \cdot 71 \pm 07 \cdot 51\end{array}$ & $\begin{array}{r}4.50 \pm 01.20 \\
149.92 \pm 98.62\end{array}$ \\
\hline $\begin{array}{l}\text { Drying } \\
\text { Number of events } \\
\text { Event length }(\mathrm{h})\end{array}$ & $\begin{array}{l}11 \cdot 57 \pm 02 \cdot 49 \\
31 \cdot 21 \pm 09 \cdot 60\end{array}$ & $\begin{array}{r}4 \cdot 00 \pm 01 \cdot 26 \\
53.93 \pm 22.82\end{array}$ \\
\hline $\begin{array}{l}\text { Other } \\
\text { Mean water level }(\mathrm{cm}) \\
\text { Volume exchange }\left(\mathrm{m}^{3} / \mathrm{m}^{2}\right. \\
\text { marsh surface) } \\
\text { Above-ground } \\
\text { Below-ground }\end{array}$ & $\begin{array}{l}0.15 \pm 0.04 \\
0.09 \pm 0.02\end{array}$ & $\begin{array}{ll}0.06 \pm 0.02 \\
0.04 \pm 0.01\end{array}$ \\
\hline
\end{tabular}

*All values, except for the volume flux estimates, represent the average monthly means \pm 2 times the standard error of the mean. The volume flux estimates are the tidal cycle means plus or minus the range of the estimate.

the total hours flooded each month for the control area against the total hours flooded each month at the partially-impounded area. The relationship is highly significant, with an $r^{2}$ value of 0.84 and a slope which is not significantly different from one. On the average, the partially-impounded area is flooded $141 \mathrm{~h} \mathrm{month}^{-1}$ more (about $33 \%$ ) than the control area.

The water-volume estimates indicated that the average above-ground water exchange per tidal cycle was $0.15 \mathrm{~m}^{3}$ and $0.06 \mathrm{~m}^{3}$ per $\mathrm{m}^{2}$ of marsh surface for the control and partially-impounded areas, respectively. Similarly, the average below-ground water volume exchange was $0.09 \mathrm{~m}^{3}$ and $0.04 \mathrm{~m}^{3}$ per $\mathrm{m}^{2}$ of marsh surface for the control and partially-impounded areas, respectively. The below-ground estimates are for ebb tide conditions only. The water-level gage deployment scheme allowed water to enter the wells from the top during flood tide conditions, thus making below-ground water exchange estimates during flood-tide conditions invalid. The above-ground estimates at each area were not significantly different for flood and ebb.

Table 1 summarizes the average hydrologic regime at the two areas. Flooding events of $100 \mathrm{~h}$ or greater occurred $10 \%$ of the time in the control marsh and $40 \%$ of the time in the partially-impounded marsh, indicating independence of water flow into and out of the marsh due to the spoil banks. Compared to the control site, the partially-impounded marsh had $65 \%$ fewer drying events but these events were $73 \%$ longer. Similarly, the partially-impounded marsh had $65 \%$ fewer flooding events, but these events were about $405 \%$ longer. The above ground water exchange was reduced by $60 \%$ and the belowground exchange was reduced by $55 \%$. The end result is an increase in flooding duration on average of $141 \mathrm{~h} \mathrm{month}^{-1}$.

\section{Discussion}

We studied one of the many partially-impounded marshes on the Louisiana coast. A cursory survey of other impounded sites indicates that there are two general types of 
impoundment: (1) those that are planned and actively managed; and (2) those that result from independent dredging and filling activities (i.e., the intersection of several canals) and hence are not planned or managed. This study was concerned with the latter case, and the general results may be broadly applicable to a significant number of these types of sites because spoil banks are built using common techniques and machinery.

Chabreck et al. (1979) monitored soil and water variables in Louisiana coastal marshes influenced by weirs. In their study, the weirs were installed in tidal channels, with the weir crest $0.15 \mathrm{~m}$ below the adjacent marsh surface, thus allowing free water exchange over the structures. The results indicated that the presence of weirs increases the percentage of time that the bottoms of marsh ponds are flooded. Our data indicate that the presence of spoil banks, which are on the marsh surface, leads to an increase in flooding over the entire marsh surface, as well as a decrease in the below-ground exchange.

Sasser (1979) described the broad empirical limits of plant distribution and flooding in these marshes, noting the wide range of flooding tolerance of plants. However, the optimum flooding conditions for plant growth are not clearly defined nor is it clear how large a disruption in the natural water-level regime can be tolerated. King et al. (1982) showed that an increase in subsurface drainage can lead to an increase in plant production, and Mendelssohn et al. (1981) showed that decreased drainage may result in less plant production. As these studies indicate, the water-level regime does influence marsh vegetation production. However, the ecological significance of the monthly hydrologic averages may be overshadowed by the few, but relatively stressful, long periods of flooding. Turner et al. (1984) showed that when marsh sediment is flooded for one week, the $\mathrm{eH}$ can drop by as much as $380 \mathrm{mV}$. Coupling the data of Turner et al. (1984) with the mean flooding event lengths measured in this study, one would expect the partiallyimpounded soil eH to fluctuate about a lower mean than the control-site soil eH. Longer periods of flooding, as are common in the impounded marsh but not in the control marsh, could result in extremely low soil eh/pH values. Such soil chemistry changes would be ecologically significant, particularly if sulphates were reduced to toxic sulfides (Mendelssohn et al., 1981; King et al., 1982; DeLaune et al., 1983).

This study has shown that canal spoil banks significantly influence the marsh waterlevel regime in this system. As the above studies indicate, these changes can have profound effects on the marsh ecosystem. In order to alleviate the adverse impacts of these hydrologic changes, management options that minimize the disruption of the hydrologic regime need to be exercised. These options include backfilling the canals, placing gaps in the spoil banks, the use of weirs or flap gates, and alternative dredging techniques not requiring spoil bank construction.

However, at the present time the degree to which the options need to be exercised, and under what conditions are not well known. What is needed now are longer-term experimental studies to investigate the marsh water-level regime together with the entire ecosystem in natural and managed wetlands. Such data would be invaluable in answering more detailed questions about the marsh ecosystem functions and would provide an improved data base to managers that would allow them to develop guidelines for these varivus marsh mitigation measures.

\section{Acknowledgements}

The authors acknowledge the contributions of their colleagues in the Coastal Ecology and Fishcrics Institutes for their support and advice. Ms Deborah Fuller, Dr James 
Gosselink, Mr Donald Moore, and Mr Charles Sasser kindly reviewed the manuscript and gave many valuable suggestions. We also thank Ms Jami Donley for her editorial comments, and Ms Terry Buckley for her patience in typing the many drafts of this manuscript. Mr Robert Abernethy, Ms Julie Amft, Mr Barnes Johnson, Mr Scott Leibowitz, Mr Chris Neill, Mr Gary Peterson, and Dr Walter Sikora assisted in the field. Ms Deborah Fuller wrote the SAS program to integrate the water level curves and gave valuable statistical advice. Mr Glenn Itano of the LSU Department of Experimental Statistics was invaluable in explaining the proper use of SAS plotting routines.

We are also thankful to the personnel of NMFS for their support and advice, particularly Mr Richard Hoogland, Mr Donald Moore, and Dr Gordon Thayer. The New Orleans District of the Corps of Engineers supplied water level data, and the Louisiana Department of Wildlife and Fisheries allowed us to process data tapes using their data translator. The Louisiana Land and Exploration Company allowed us to construct measuring stations on their property.

This study was supported through the National Marine Fisheries Service, under an IPA Agreement (Contract No. NA81-BA-P00006).

This is Coastal Ecology Institute Publication LSU-CEI-85-03.

\section{References}

Adams, R. D., Banas, P. J., Baumann, R. H., Blackmon, J. H. \& McIntire, W. A. 1978 Shoreline Erosion in Coastal Louisiana: Inventory and Assessment. Final Report to Louisiana Department of Transportation and Development, Center for Wetland Resources, Louisiana State University, Baton Rouge, LA 70803.

Chabreck, R. 1972 Vegetation, water and soil characteristics of the Lousiana coastal region. LSU Agricultural Experiment Station Bulletin Number 664. Baton Rouge, Louisiana.

Chabreck, R., Hoar, R. J. \& Larrick Jr, W. D. 1979 Soil and water characteristics of coastal marshes influenced by weirs. In: Proceedings of the Third Coastal Marsh and Estuary Management Symposium (J. W. Day Jr, D. D. Culley Jr, R. E. Turner \& A. J. Mumphrey Jr, eds), pp. 127-146. Division of Continuing Education, Louisiana State University, Baton Rouge, LA.

Craig, N. J., Turner, R. E. \& Day Jr, J. W. 1979 Land loss in coastal Louisiana. Environmental Management 3, 133-144.

DeLaune, R. D., Smith, C. J. \& Patrick Jr, W. H. 1983 Relationship of marsh elevation, Redox potential, and Sulfide to Spartina alterniflora Productivity. Soil Science Am. F. 47, 930-935.

Gael, B. T. \& Hopkinson, C. S. 1979 Drainage density, land-use and eutrophication in Barataria Basin, Louisiana. In: Proceedings of the Third Coastal Marsh and Estuary Management Symposium (J. W. Day Jr, R. D. Culley Jr, R. E. Turner \& A. J. Mumphrey Jr, eds) pp. 147-163. Division of Continuing Education, Louisiana State University, Baton Rouge, LA 70803.

King, G. M., Klug, M. J., Weigert, R. G. \& Chalmers, A. G. 1982 Relation of soilwater movement and sulfide concentration to Spartina alterniflora production in a Georgia salt marsh. Science 218, 61-63.

Mendelssohn, I. A., McKee, K. L. \& Patrick Jr, W. H. 1981 Oxygen deficiency in Spartina alterniflora roots: metabolic adaptation to anoxia. Science 214, 439-441.

SAS Institute Inc. $1981 S A S /$ Graph User's Guide, 1981 edition. Cary, North Carolina.

SAS Institute Inc. $1982 a$ SAS User's Guide: Basics, 1982 edition. Cary, North Carolina.

SAS Institute Inc. $1982 b$ SAS User's Guide: Statistics, 1982 edition. Cary, North Carolina.

Sasser, C. E. 1979 Distribution of vegetation. In: Louisiana Coastal Marshes as Response to Tidal Flooding. M.S. Thesis, Dept. of Marine Sciences, Louisiana State University, Baton Rouge, LA.

Scaife, W., Turner, R. E. \& Costanza, R. 1983 Coastal Louisiana recent land loss and canal impacts. fournal of Environmental Management 7, 433-442.

Swenson, E. M. 1983 Marsh Hydrologic Studies: 1982-1983 Data Report. Prepared for the National Marine Fisheries Service, St Petersburg, F1. Contract No. NA81-BA-P00006. Center for Wetland Resources, Louisiana State University, Baton Rouge, LA 70803. LSU-CEFI-83-18.

Turner, R. E. \& Gosselink, J. G. 1975 A note on standing crops of Spartina alterniflora in Texas and Florida. Contributions to Marine Science 19, 113-118.

Turner, R. E., Costanza, R. \& Scaife, W. 1982 Canals and wetland erosion rates in coastal Louisiana. In: Proceedings of the Conference on Coastal Erosion and Wetland Modification in Louisiana: Causes, Consequences, and Options (D. Boesch, ed.). U.S. Fish and Wildlife Service, Biological Services Program, FWS/OBS-82/59. 
Turner, R. E., Kreidler, R. \& Neill, C. 1984 Experimental manipulations of marsh hydrology and their significance to marsh management. In: Evaluation of Backfilling Canals as a means of Mitigating the Environmental Impact of Canals Chapter 6. Center for Wetland Resources, Louisiana State University, Baton Rouge, LA 70803. Prepared for Coastal Zone Management Section, Dept. of Natural Resources, P.O. Box 44124, Baton Rouge, LA 70804. 